\title{
Quantum dot imaging for HSP70 and HSF-1 kinetics in SCC-25 cells with or without leucine deprivation following heat shock
}

\author{
JUN CHEN, JIE PAN, JIANJIANG ZHAO, XIAOLING QIU, JUNFA ZHENG, \\ ZHIPING WANG, YUHUA HUANG and HONGXING CHU
}

Guangdong Provincial Stomatological Hospital, Southern Medical University, Guangzhou, Guangdong 510280, P.R. China

Received December 14, 2012; Accepted March 4, 2013

DOI: $10.3892 /$ or.2013.2372

\begin{abstract}
The aim of this study was to develop a quantum dot-based approach for heat shock protein 70 (HSP70) and heat shock factor 1 (HSF-1) kinetics following heat shock, and to discover approaches to thermotherapy based on disrupting the effect of activation of HSF-1 and the accumulation of HSP70 by leucine deprivation. SCC-25 cells cultured with limiting leucine or normal leucine were stressed at $42^{\circ} \mathrm{C}$ for $30 \mathrm{~min}$, and were cultured for 2, 4, 6, 8 and $10 \mathrm{~h}$, respectively. The expression of HSP70 and HSF-1 was observed using confocal laser microscopy and semi-quantitative analysis was performed by Image-Pro Plus. At $6 \mathrm{~h}$ after heating, HSF-1 in cells cultured with normal leucine was activated and translocated from the cytosol to the nucleus, and the synthesis of HSP70 reached the maximum value and had a tendency to gather in the nucleus. However, in cells cultured with limiting leucine, HSF-1 activity decreased and accumulation of HSP70 was not found. Leucine deprivation results in the inactivation of HSF-1 leading to slight accumulation of HSP70 and no tendency to gather in the nucleus. Thus, HSF-1 may serve as a novel therapeutic target in the treatment of oral cancer.
\end{abstract}

\section{Introduction}

Oral squamous cell carcinoma (OSCC) is a common malignant tumor and the leading cause of oral cancer-related mortality (1-6). In China, the incidence of OSCC has been on a steady rise, and the thermotherapy targeted to heat shock protein 70 (HSP70) has a marked impact on OSCC

Correspondence to: Professor Jianjiang Zhao, Department of Oral Surgery, Guangdong Provincial Stomatological Hospital, Southern Medical University, 366 Jiangnan Street, Guangzhou, Guangdong 510280, P.R. China

E-mail: zjj2521@sina.com

Key words: quantum dot, protein kinetics, heat stress, heat shock protein 70 , heat shock factor 1 , oral squamous cell carcinoma, leucine deprivation treatment $(7,8)$. HSP70 is known to assist the folding of nascent polypeptide chains, act as a molecular chaperone and mediate the repair and degradation of altered or denatured proteins. The ability of cells to respond to stress by increasing their HSP levels depends on the activity of heat shock factor (HSF). HSF-1 is known for its activation of transcription of the HSP genes during proteotoxic stress which can bind to the 50 promoter regions of all HSP genes and trigger instantaneous and massive transcription of these stress protein genes. The HSF-1/HSP system plays an important role in OSCC prognosis and treatment selection, being associated with a disparate range of tumor initiators and promoters. This system has thus emerged as a source for potential biomarkers of cell transformation and tumor progenesis. The status of HSP70 and HSF-1 is an integral part of the clinicopathological practice of OSCC, and accurate HSP70 and HSF-1 quantification and co-localization is crucial for treatment strategies (9).

The new semiconductor nanocrystals, quantum dots (QDs), are fluorescent semiconductor nanocrystals with a 2-10 $\mathrm{nm}$ core diameter, possessing several advantages over conventional fluorescent dyes, such as wide excitation spectra, significant photostability and a long fluorescence lifespan (10-18). These characteristics have attracted considerable interest in their application in immunohistochemistry for biomarker quantification and co-localization in oral tumors for prognosis and treatment (20-31). The present study sought to develop a QD-based approach for a long dynamic observation of physiological changes of HSP70 and HSF-1 in SCC-25 cells induced by heat shock, and to discover approaches to disrupt the influence of activation of HSF-1 and the accumulation of HSP70 in oral cancer.

\section{Materials and methods}

Materials. QDs (goat anti-mouse $\mathrm{QD}_{525 \mathrm{~nm}}$-IgG and goat antimouse $\left.\mathrm{QD}_{655 \mathrm{~nm}}-\mathrm{IgG}\right)$ were purchased from Invitrogen. Mouse anti-human HSP70 antibody and mouse anti-human HSF-1 antibody was provided by Abcam. DMEM/F12 medium with or without leucine and trypsin were purchased from Sigma. The laser confocal microscope used was Leica TCS SP2, Germany. 

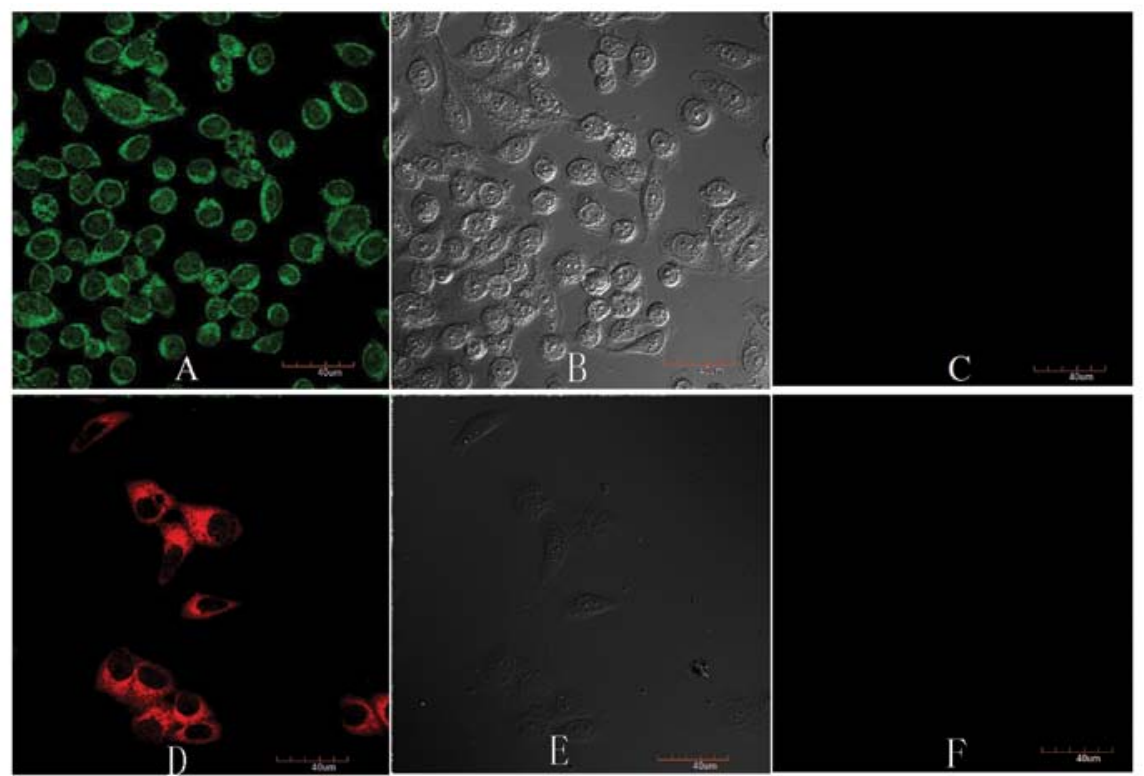

Figure 1. Fluorescence imaging of HSP70 and HSF-1 tagged by $\mathrm{QD}_{525 \mathrm{~nm}}$ or $\mathrm{QD}_{655 \mathrm{~nm}}$. $\mathrm{QD}_{525 \mathrm{~mm}}$-marked HSP70 was clearly expressed in the cytoplasm and nucleus of SCC-25 cells, and was mainly distributed in the cytoplasm (A). The QD $_{655 \mathrm{~nm}}$-marked HSF-1 was expressed in the cytoplasm (D).

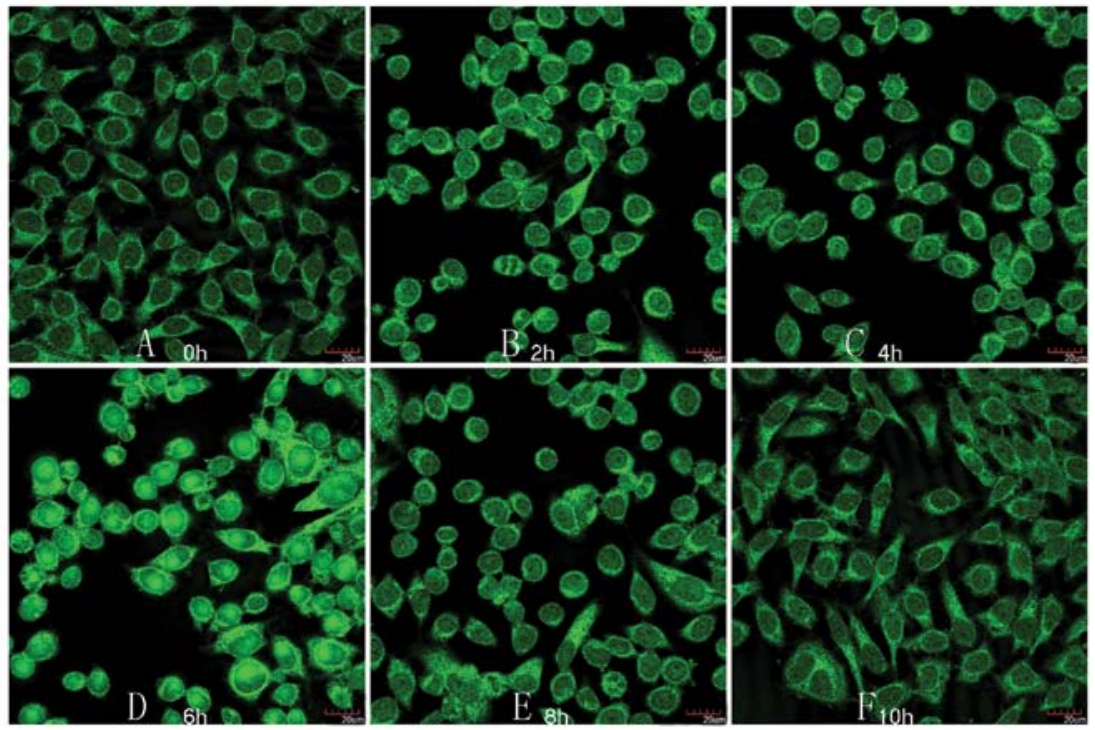

Figure 2. HSP70 kinetics in cells cultured with normal leucine following heat shock at (A) $0 \mathrm{~h}$, (B) $2 \mathrm{~h}$, (C) $4 \mathrm{~h}$, (D) $6 \mathrm{~h}$, (E) $8 \mathrm{~h}$ and (F) $10 \mathrm{~h}$. The synthesis of HSP70 in cells cultured with normal leucine began to increase at $2 \mathrm{~h}(\mathrm{~B})$, reached the maximum value and had a tendency to gather in the nucleus at $6 \mathrm{~h}(\mathrm{D})$.

\section{Methods}

Cell culture. For the cell culture, SCC-25 cells were cultured in DMEM/F12 medium (Sigma) with or without leucine and were placed in an incubator containing a 5\% volume fraction of $\mathrm{CO}_{2}$ at $37^{\circ} \mathrm{C}$. The culture medium was changed every 2 days, and $0.25 \%$ trypsin was used to digest and subculture the cells after 2-3 days.

Cell inoculation. For the cell inoculation, the digested cells were inoculated onto a confocal-dedicated utensil at a density of $\sim 1 \times 10^{5}$ cells. After culturing for 1-2 days, the cells were $80 \%$ confluent.

Heat stress. For the heat stress (32), cells were stressed at $42^{\circ} \mathrm{C}$ for 30 min (groups A, B, C, D, E and F). Following incuba- tion at $37^{\circ} \mathrm{C}$ constant temperature, immunofluorescence was performed on all groups after $0 \mathrm{~h}$ (group A), $2 \mathrm{~h}$ (group B), $4 \mathrm{~h}$ (group C), $6 \mathrm{~h}$ (group D), $8 \mathrm{~h}$ (group E) and $10 \mathrm{~h}$ (group F).

Cell fixation. For the cell fixation, all groups were washed twice with $0.01 \mathrm{~mol} / \mathrm{l}(\mathrm{pH}$ 7.4) TBS and were fixed with prechilled methanol for $10 \mathrm{~min}$.

Immunofluorescence. For the immunofluorescence, the fixed SCC-25 cells were washed with TBS, incubated with Triton $\mathrm{X}-100$ for $10 \mathrm{~min}$ and washed. They were then incubated at $4{ }^{\circ} \mathrm{C}$ overnight with mouse anti-human HSP70 antibody or mouse anti-human HSF-1 antibody (dilution ratios were 1:100). The cells were then washed 3 times in TBS and were incubated 

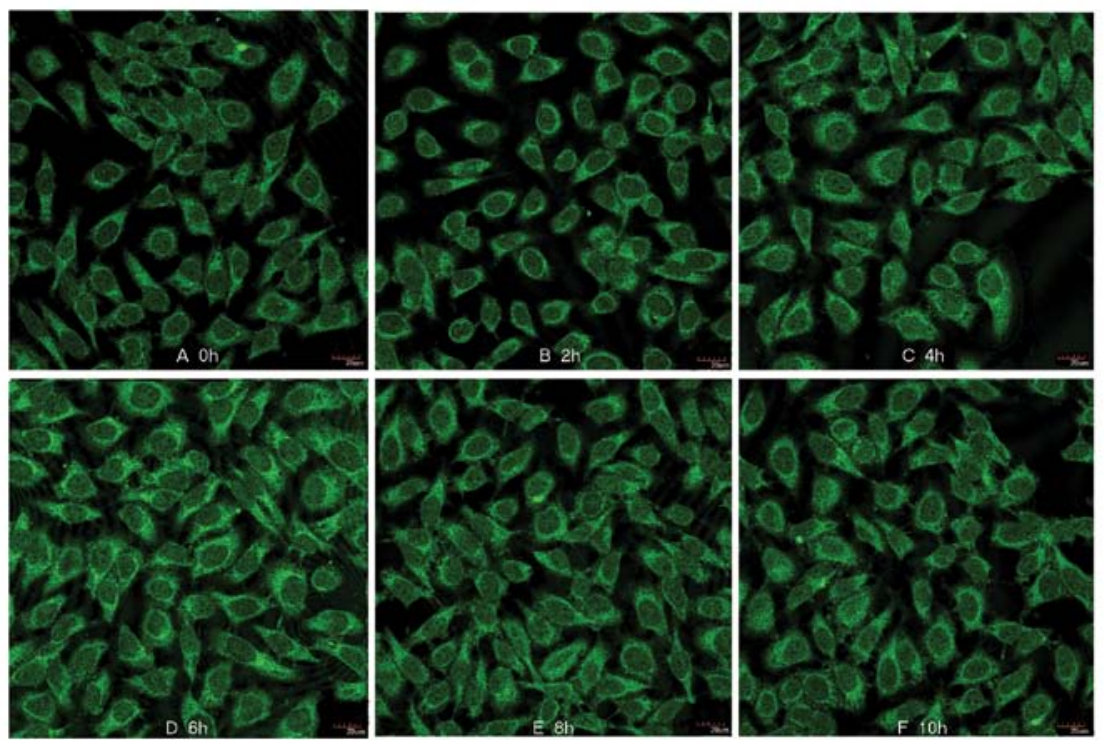

Figure 3. HSP70 kinetics in cells cultured with limiting leucine following heat shock at (A) $0 \mathrm{~h}$, (B) $2 \mathrm{~h}$, (C) $4 \mathrm{~h}$, (D) $6 \mathrm{~h}$, (E) $8 \mathrm{~h}$ and (F) $10 \mathrm{~h}$. The synthesis of HSP70 in cells cultured with limiting leucine showed a litter increase at $6 \mathrm{~h}$, but the accumulation of HSP70 had no tendency to gather in the nucleus (D).
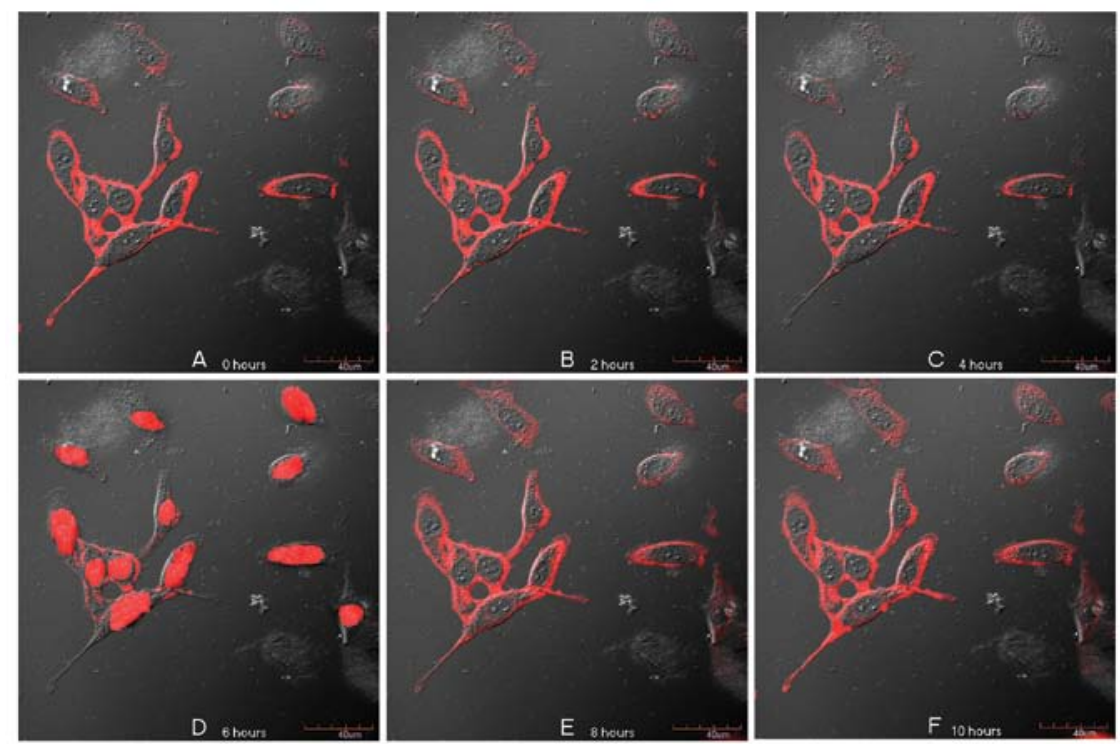

Figure 4. HSF-1 kinetics in cells cultured with normal leucine following heat shock at (A) $0 \mathrm{~h}$, (B) $2 \mathrm{~h}$, (C) $4 \mathrm{~h}$, (D) $6 \mathrm{~h}$, (E) $8 \mathrm{~h}$ and (F) $10 \mathrm{~h}$. The majority of HSF-1 was localized in the plasma membrane cytoplasm at $0,2,4,8$ and $10 \mathrm{~h}$. However, at $6 \mathrm{~h}$ after heating at $42^{\circ} \mathrm{C}$ for 30 min, an increasing number of HSF-1 translocated from the cytosol to the nucleus, similar to the translocation of HSP70 (D).

with buffer solution in a $37^{\circ} \mathrm{C}$ moist box for $10 \mathrm{~min}$, followed by incubation with the equivalent mixed liquid of goat antimouse $\mathrm{QD}_{525 \mathrm{~mm}}-\mathrm{IgG}$ or goat anti-mouse $\mathrm{QD}_{655 \mathrm{~nm}}-\mathrm{IgG}(1: 100)$ in a $37^{\circ} \mathrm{C}$ moist box for $45 \mathrm{~min}$. Finally, the cells were washed three times with TBST and sent for detection away from light. Each experiment was repeated 5 times.

Detection under laser confocal fuorescence microscopy and analysis by Image-Pro Plus. The wavelength of excitation spectra was $488 \mathrm{~nm}$ and the constant temperature system was adjusted to $30^{\circ} \mathrm{C}$.

Statistical analysis. Data are expressed as the means \pm SD. Comparisons between two groups were conducted by one-way
ANOVA. P $\leq 0.05$ was considered to indicate a statistically significant difference.

\section{Results}

$H S P 70$ and HSF-1 labeled by $Q D_{525 n m}$ or $Q D_{655 n m}$. With a laser confocal microscopy, $\mathrm{QD}_{525 \mathrm{~nm}}$-marked HSP70 was clearly expressed in the cytoplasm and nucleus of SCC-25 cells, mainly distributed in the cytoplasm (Fig. 1A). The $\mathrm{QD}_{655 \mathrm{~mm}^{-}}$ marked HSF-1 was expressed in the cytoplasm (Fig. 1D).

HSP70 kinetics in cells cultured with normal leucine or limiting leucine. With a laser confocal microscopy, the synthesis of HSP70 in cells cultured with normal leucine 

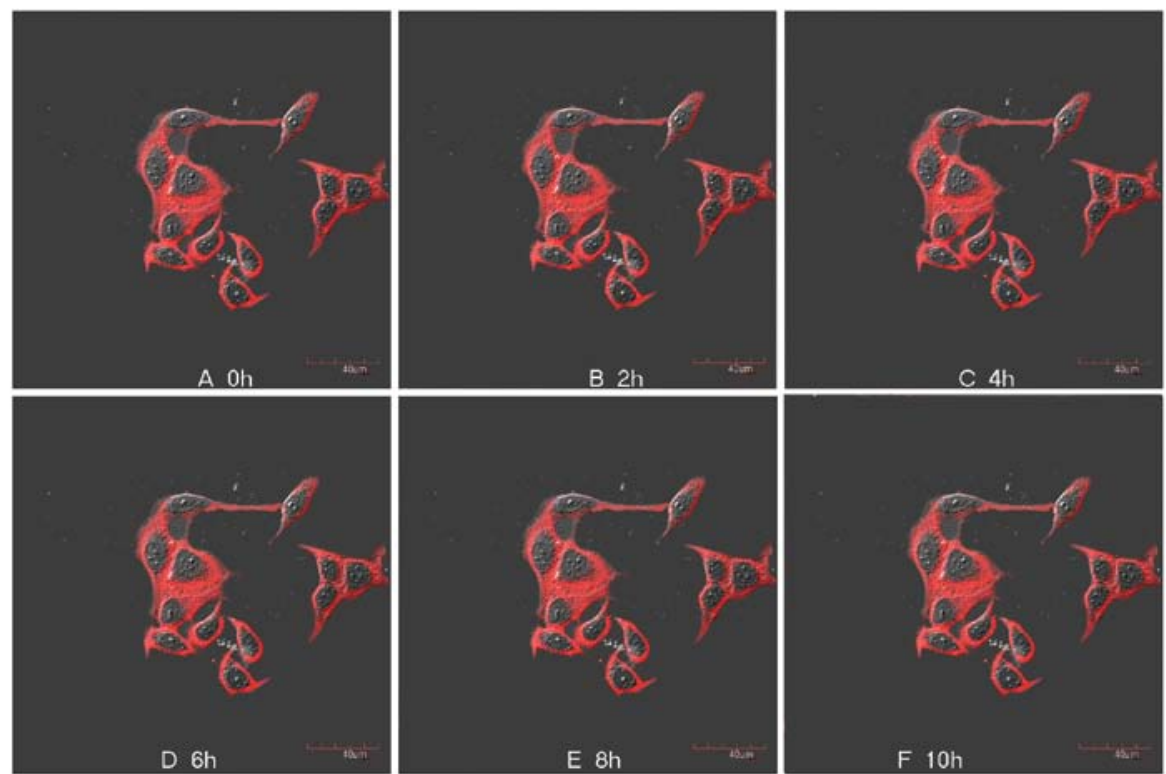

Figure 5. HSF-1 kinetics in cells cultured with limiting leucine during all the recovery periods of heat shock at (A) $0 \mathrm{~h}$, (B) $2 \mathrm{~h}$, (C) $4, \mathrm{~h}$ (D) $6 \mathrm{~h}$, (E) $8 \mathrm{~h}$ and (F) $10 \mathrm{~h}$. The lymphocyte positioning of HSF-1 in cells cultured with limiting leucine showed only slight change. HSF-1 translocation from the cytosol to the nucleus was not observed at $6 \mathrm{~h}$ after heat shock (D).

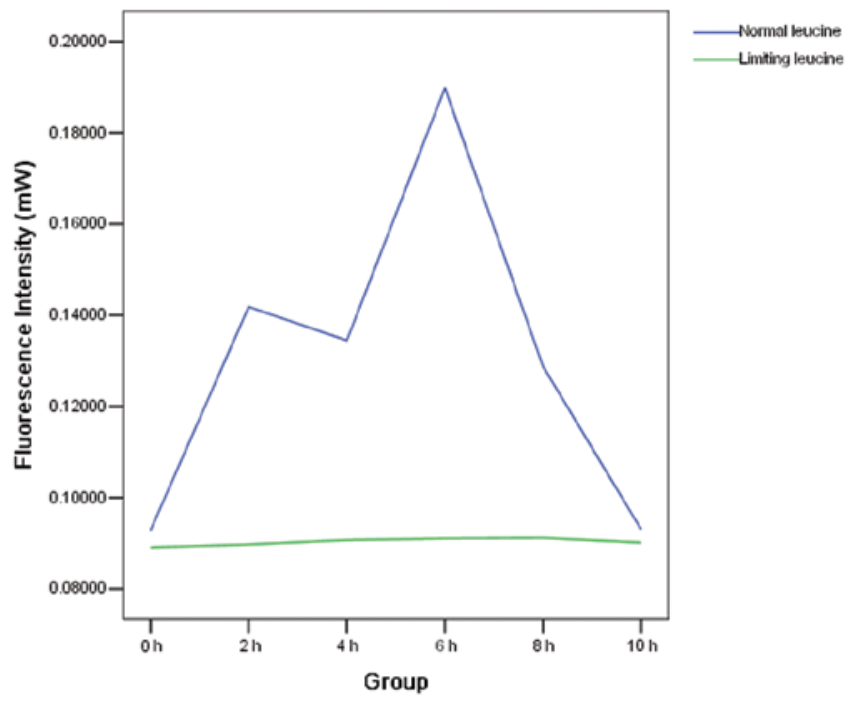

Figure 6. Semi-quantitative determination of HSP70 in cells cultured with limiting leucine or normal leucine during all the recovery periods of heat shock.

began to increase at $2 \mathrm{~h}$ (Fig. 2B), they reached the maximum value at $6 \mathrm{~h}$, and had a tendency to gather in the nucleus at $6 \mathrm{~h}$ (Fig. 2D).

However, the synthesis of HSP70 in cells cultured with limiting leucine showed a small increase at $6 \mathrm{~h}$ (Fig. 3D). The accumulation of HSP70 showed no tendency to gather in the nucleus (Fig. 3D), whereas cells without leucine deprivation showed a translocation from the cytoplasm to the nucleus (Fig. 2D) at $6 \mathrm{~h}$.

HSF-1 kinetics in cells cultured with normal leucine or limiting leucine. In an attempt to elucidate the difference of the HSP70 kinetics between the limiting leucine and the normal leucine group, we investigated the dynamic distribution of HSF-1 under laser confocal fluorescence microscopy.

The subcellular localization of HSF-1 in cells cultured with normal leucine was different during the recovery periods of heat shock (Fig. 4). The majority of HSF-1 was found to be localized in the cytoplasm at $0,2,4,8$ and $10 \mathrm{~h}$ after heating at $42^{\circ} \mathrm{C}$ for $30 \mathrm{~min}$ (32). However, at $6 \mathrm{~h}$, an increasing number of HSF-1 translocated from the cytoplasm to the nucleus (Fig. 4D), similar to the translocation of HSP70 (Fig. 2D).

By contrast, in cells cultured with limiting leucine, the subcellular localization of HSF-1 presented only a slight change, HSF-1 was localized in the cytoplasm during the recovery periods of heat shock, and no translocation was observed at $6 \mathrm{~h}$ after heat shock (Fig. 5D).

Semi-quantitative determination of HSP70 in cells cultured with limiting leucine or normal leucine during all the recovery periods of heat shock. HSP70 was detected in each group five times and 65 photofluorograms of each group were analyzed by Image-Pro Plus. Results are expressed as means \pm SD.

As indicated in Table I and Fig. 6, the synthesis of HSP70 in cells cultured with normal leucine had a significant increase at $2 \mathrm{~h}$ after the heat shock $(\mathrm{P}<0.05)$. It reached the maximum value at $6 \mathrm{~h}(0.1898172 \pm 0.00219462$ vs. $0.0928257 \pm 0.00193721$ at $0 \mathrm{~h} ; \mathrm{P}<0.05)$, and it began to decrease at $8 \mathrm{~h}$. At $10 \mathrm{~h}$, it returned to the level at $0 \mathrm{~h}$.

The synthesis of HSP70 in cells cultured with limiting leucine demonstrated a small increase during all the recovery periods of heat shock ( $\mathrm{P}>0.05)$ (Table II and Fig. 6).

Concurrently, the synthesis of the HSP70 in cells cultured with normal leucine significantly increased compared to that of the HSP70 in cells cultured with limiting leucine at 2, 4, 6 and $8 \mathrm{~h}(\mathrm{P}<0.05)$. 


\section{Discussion}

Heat shock proteins (HSPs) were first identified as stress proteins that confer resistance to physical stresses such as elevated temperatures in all cellular organisms (33-36). HSP70 expression becomes deregulated in oral cancer. Elevated HSP70 expression leads to resistance to subsequent thermotherapy.

In the present study, we developed the QD-IHC protocol for HSP70 kinetics in SCC-25 cells cultured with or without leucine following heat shock. At $6 \mathrm{~h}$ after heating at $42^{\circ} \mathrm{C}$ for $30 \mathrm{~min}$, the synthesis of the HSP70 in cells without leucine deprivation increased approximately 2 -fold whereas that of cells with leucine deprivation showed only a small increase. Particularly the accumulation of HSP70 in cells cultured with normal leucine had a tendency to gather in the nucleus at $6 \mathrm{~h}$ whereas cells with leucine deprivation showed no translocation. Concurrently, the synthesis of HSP70 in the normal leucine group was increased significantly compared to that of the limiting leucine group at 2, 4, 6 and $8 \mathrm{~h}$, respectively $(\mathrm{P}<0.05)$.

In an attempt to elucidate the mechanisms of HSP70 kinetics associated with leucine deprivation, we investigated the dynamic distribution of HSF-1 in SCC-25 cells cultured with or without leucine following heat shock. HSF-1 is known for its activation of transcription of the HSP genes during heat shock (37-42); it possesses a complex modular structure with several functional domains such as the DNA-binding domain (DBD; residues 15-120) and trimerization domains (residues 130-203). The trimerization domain is composed of three arrays of hydrophobic heptad repeats (HR-A/B). When the HSF-1 monomers come together, they form a leucine zipper, an artifact typically seen in dimerization. Once the heat shock response is induced, HSF-1 is activated through trimerization, accumulation in the nucleus, post-translational modifications and binding to HSP genes through DBD.

Leucine is one of the three branched chain amino acids (BCAA) along with isoleucine and valine. Leucine is the most prominent of the three and is the sole amino acid behind the branched chain amino acid stimulation of protein synthesis and anti-catabolic actions. Leucine deprivation results in the inactivation of HSF-1, and leads to a sharp decrease in the transcript level of HSF-1 target genes such as HSPA1A (HSP70), DNAJB1 (HSP40) and HSP90AA1 (43).

In leucine-deprived cells, HSF-1 loses its DBD activity and the HSF-1 monomer trimerization, accumulation in the nucleus and post-translational modifications were all inhibited. Leucine deprivation results in the inactivation of HSF-1, leading to slight accumulation of HSP70 in the nucleus.

With the valuable research tools for tumor prognosis and treatment (44-47), protein kinetics with QD provide a rationale for thermotherapy accompanied by short-term dietary restriction of leucine in patients with oral tumor.

In conclusion, the HSF-1/HSP system is implicated in several crucial steps in oncogenesis and tumor progression, activated HSF-1 and increased HSP levels may aid in the oncodiagnosis and treatment in the clinic. Leucine deprivation can disrupt the influence of activation of HSF-1 and the accumulation of HSP70 following heat shock. Thermotherapy accompanied by short-term dietary restriction of leucine may be a novel approach for the treatment of oral cancer. 


\section{References}

1. Parkin DM, Pisani P and Ferlay J: Estimates of the worldwide incidence of eighteen major cancers in 1985. Int J Cancer 54: 594-606, 1993.

2. Camisasca DR, Silami MA, Honorato J, Dias FL, Faria PA and Lourenço SD: Oral squamous cell carcinoma: clinicopathological features in patients with and without recurrence. ORL J Otorhinolaryngol Relat Spec 73: 170-176, 2011.

3. Uchida K, Oga A, Nakao M, Mano T, Mihara M, Kawauchi S, Furuya T, Ueyama Y and Sasaki K: Loss of 3p26.3 is an independent prognostic factor in patients with oral squamous cell carcinoma. Oncol Rep 26: 463-469, 2011.

4. Hanash SM, Bobek MP, Rickman DS, Williams T, Rouillard JM Kuick R and Puravs E: Integrating cancer genomics and proteomics in the post-genome era. Proteomics 2: 69-75, 2002.

5. Snyder M and Gerstein M: Genomics. Defining genes in the genomics era. Science 300: 258-260, 2003.

6. Fields S: Proteomics in genomeland. Science 291: 1221-1224, 2001.

7. Carr KM, Rosenblatt K, Petricoin EF, et al: Genomic and proteomic approaches for studying human cancer: prospects for true patient-tailored therapy. Hum Genomics 1: 134-140, 2004.

8. Lee SS, Tsai CH, Ho YC and Chang YC: The upregulation of heat shock protein 70 expression in areca quid chewing-associated oral squamous cell carcinomas. Oral Oncol 44: 884-890, 2008.

9. Markopoulos AK, Deligianni E and Antoniades DZ: Heat shock protein 70 membrane expression in oral cancer: a possible new target in antineoplastic therapy? Chemotherapy 55: 211-214, 2009.

10. Zhao JJ, Chen J, Wang ZP, Pan J and Huang YH: Double labeling and comparison of fluorescence intensity and photostability between quantum dots and FITC in oral tumors. Mol Med Report 4: 425-429, 2011.

11. Doty RC, Fernig DG and Levy R: Nanoscale science: a big step towards the Holy Grail of single molecule biochemistry and molecular biology. Cell Mol Life Sci 61: 1843-1849, 2004.

12. Hanaki K, Momo A, Oku T, Komoto A, Maenosono S, Yamaguchi Y and Yamamoto K: Semiconductor quantum dot/albumin complex is a long-life and highly photostable endosome marker. Biochem Biophys Res Commun 302: 496-501, 2003.

13. McMahon RJ: Chemical reactions involving quantum tunneling. Science 299: 833-834, 2003.

14. Banerjee B, Miedema B and Chandrasekhar HR: Emission spectra of colonic tissue and endogenous fluorophores. Am J Med Sci 316: 220-226, 1998.

15. Alivisatos P: The use of nanocrystals in biological detection. Nat Biotechnol 22: 47-52, 2004.

16. Garon EB, Marcu L, Luong Q, Tcherniantchouk O, Crooks GM and Koeffler HP: Quantum dot labeling and tracking of human leukemic, bone marrow and cord blood cell. Leuk Res 31: 643-651, 2007.

17. Bruchez M Jr, Moronne M, Gin P, Weiss S and Alivisatos AP: Semiconductor nanocrystals as fluorescent biological labels. Science 281: 2013-2016, 1998.

18. Wang HZ, Wang HY, Liang RQ and Ruan KC: Detection of tumor marker CA125 in ovarian carcinoma using quantum dots. Acta Biochim Biophys Sin 36: 681-686, 2004.

19. Li Z, Wang K, Tan W, Li J, Fu Z, Ma C, Li H, He X and Liu J: Immunofluorescent labeling of cancer cells with quantum dots synthesized in aqueous solution. Anal Biochem 354: 169-174, 2006.

20. Yezhelyev MV, Gao X, Xing Y, Al-Hajj A, Nie S and O'Regan RM: Emerging use of nanoparticles in diagnosis and treatment of breast cancer. Lancet Oncol 7: 657-667, 2006.

21. Tholouli E, Hoyland JA, Di Vizio D, O'Connell F, Macdermott SA, Twomey D, Levenson R, Yin JA, Golub TR, Loda M and Byers R: Imaging of multiple mRNA targets using quantum dot based in situ hybridization and spectral deconvolution in clinical biopsies. Biochem Biophys Res Commun 348: 628-636, 2006.

22. Azzazy HM, Mansour MM and Kazmierczak SC: From diagnostics to therapy: prospects of quantum dots. Clin Biochem 40 917-927, 2007.

23. Wu X, Liu H, Liu J, Haley KN, Treadway JA, Larson JP, Ge N, Peale F and Bruchez MP: Immunofluorescent labeling of cancer marker Her2 and other cellular targets with semiconductor quantum dots. Nat Biotechnol 21: 41-46, 2003.

24. Lidke DS, Nagy P, Heintzmann R, Arndt-Jovin DJ, Post JN, Grecco HE, Jares-Erijman EA and Jovin TM: Quantum dot ligands provide new insights into erbB/HER receptor-mediated signal transduction. Nat Biotechnol 22: 198-203, 2004.
25. Jaiswal JK, Mattoussi H, Mauro JM and Simon SM: Long-term multiple color imaging of live cells using quantum dot bioconjugates. Nat Biotechnol 21: 47-51, 2003.

26. Chan WC, Maxwell DJ, Gao X, Bailey RE, Han M and Nie S: Luminescent quantum dots for multiplexed biological detection and imaging. Curr Opin Biotechnol 13: 40-46, 2002.

27. Hall M, Kazakova I and Yao YM: High sensitivity immunoassays using particulate fluorescent labels. Anal Biochem 272: 165-170, 1999 .

28. Gao X, Cui Y, Levenson RM, Chung LW and Nie S: In vivo cancer targeting and imaging with semiconductor quantum dots. Nat Biotechnol 22: 969-976, 2004

29. Medintz IL, Uyeda HT, Goldman ER and Mattoussi H: Quantum dot bioconjugates for imaging, labelling and sensing. Nat Mater 4: 435-446, 2005.

30. Sukhanova A, Devy J, Venteo L, Kaplan H, Artemyev M, Oleinikov V, Klinov D, Pluot M, Cohen JH and Nabiev I: Biocompatible fluorescent nanocrystals for immunolabeling of membrane proteins and cells. Anal Biochem 324: 60-67, 2004.

31. Zahavy E, Freeman E, Lustig S, Keysary A and Yitzhaki S: Double labeling and simultaneous detection of B- and T cells using fluorescent nano-crystal (q-dots) in paraffin-embedded tissues. J Fluoresc 15: 661-665, 2005.

32. Abe T, Gotoh S and Higashi K: Higher induction of heat shock protein 72 by heat stress in cisplatin-resistant than in cisplatinsensitive cancer cells. Biochim Biophys Acta 1445: 123-133, 1999.

33. Tavassol F, Starke OF, Kokemüller H, Wegener G, MüllerTavassol CC, Gellrich NC and Eckardt A: Prognostic significance of heat shock protein 70 (HSP70) in patients with oral cancer. Head Neck Oncol 3: 10, 2011

34. Park SR, Lee KD, Kim UK, Gil YG, Oh KS, Park BS and Kim GC: Pseudomonas aeruginosa exotoxin A reduces chemoresistance of oral squamous carcinoma cell via inhibition of heat shock proteins 70 (HSP70). Yonsei Med J 51: 708-716, 2010.

35. Chen X, Tao Q, Yu H, Zhang L and Cao X: Tumor cell membranebound heat shock protein 70 elicits antitumor immunity. Immunol Lett 84: 81-87, 2002.

36. Thiel UJ, Feltens R, Adryan B, Gieringer R, Brochhausen C, Schuon R, Fillies T, Grus F, Mann WJ and Brieger J: Analysis of differentially expressed proteins in oral squamous cell carcinoma by MALDI-TOF MS. J Oral Pathol Med 40: 369-379, 2011.

37. Akerfelt M, Morimoto RI and Sistonen L: Heat shock factors: integrators of cell stress, development and lifespan. Nat Rev Mol Cell Biol 11: 545-555, 2010.

38. Westerheide SD and Morimoto RI: Heat shock response modulators as therapeutic tools for diseases of protein conformation. J Biol Chem 280: 33097-33100, 2005.

39. Clos J, Westwood JT, Becker PB, Wilson S, Lambert K and $\mathrm{Wu} \mathrm{C}$ : Molecular cloning and expression of a hexameric Drosophila heat shock factor subject to negative regulation. Cell 63: 1085-1097, 1990.

40. Sorger PK and Pelham HR: Yeast heat shock factor is an essential DNA-binding protein that exhibits temperature-dependent phosphorylation. Cell 54: 855-864, 1988.

41. Wiederrecht G, Seto D and Parker CS: Isolation of the gene encoding the $S$. cerevisiae heat shock transcription factor. Cell 54: 841-853, 1988.

42. Westerheide SD, Raynes R, Powell C, Xue B and Uversky VN: HSF transcription factor family, heat shock response, and protein intrinsic disorder. Curr Protein Pept Sci 13: 86-103, 2012.

43. Hensen SM, Heldens L, van Enckevort CM, van Genesen ST, Pruijn GJ and Lubsen NH: Heat shock factor 1 is inactivated by amino acid deprivation. Cell Stress Chaperones 17: 743-755, 2012.

44. Xiao Y and Gao X: Use of IgY antibodies and semiconductor nanocrystal detection in cancer biomarker quantitation. Biomark Med 4: 227-239, 2010.

45. Sweeney E, Ward TH, Gray N, Womack C, Jayson G, Hughes A, Dive $\mathrm{C}$ and Byers R: Quantitative multiplexed quantum dot immunohistochemistry. Biochem Biophys Res Commun 374: 181-186, 2008.

46. Xing Y, Chaudry Q, Shen C, Kong KY, Zhau HE, Chung LW, Petros JA, O'Regan RM, Yezhelyev MV, Simons JW, Wang MD and Nie S: Bioconjugated quantum dots for multiplexed and quantitative immunohistochemistry. Nat Protoc 2: 1152-1165, 2007.

47. Byers RJ, Di Vizio D, O'connell F, Tholouli E, Levenson RM, Gossage K, Twomey D, Yang Y, Benedettini E, Rose J, Ligon KL, Finn SP, Golub TR and Loda M: Semiautomated multiplexed quantum dot-based in situ hybridization and spectral deconvolution. J Mol Diagn 9: 20-29, 2007. 